Article

\title{
Evaluation of Strategies to Improve the Corporate Social Responsibility Performance in Food and Pharmaceutical Industries: Empirical Evidence from Iran
}

\author{
Sara Mehrab Daniali ${ }^{1, *}$, Sergey Evgenievich Barykin ${ }^{1, *}{ }^{\mathbb{C}}$, Mostafa Ghanbari Ghalerodkhani ${ }^{2}$, \\ Andrey Viktorovich Kharlamov ${ }^{3}$, Tatiana Lvovna Kharlamova ${ }^{4}$, Oksana Vladimirovna Savvina ${ }^{5}$ \\ and Diana Igorevna Stepanova 5 (D) \\ 1 Graduate School of Service and Trade, Peter the Great St. Petersburg Polytechnic University, \\ Polytechnicheskaya, 29, 195251 St. Petersburg, Russia \\ 2 Department of Accounting, Fuman \& Shaft Branch, Islamic Azad University, Fuman 3587543518, Iran; \\ ghanbari.chamran219@gmail.com \\ 3 Chair of General Economic Theory and the History of Economic Thought, St. Petersburg State University \\ of Economics, 191023 St. Petersburg, Russia; kharlamov_2000@list.ru \\ 4 Graduate School of Industrial Management, Peter the Great St. Petersburg Polytechnic University, \\ Polytechnicheskaya, 29, 195251 St. Petersburg, Russia; kharlamova_t@list.ru \\ 5 Department of Finance and Prices, Plekhanov Russian University of Economics, 117997 Moscow, Russia; \\ osavvina@yandex.ru (O.V.S.); s_diana@mail.ru (D.I.S.) \\ * Correspondence: sara_danial64@yahoo.com (S.M.D.); sbe@list.ru (S.E.B.)
}

\section{check for} updates

Citation: Daniali, S.M.; Barykin, S.E.; Ghalerodkhani, M.G.; Kharlamov,

A.V.; Kharlamova, T.L.; Savvina, O.V.; Stepanova, D.I. Evaluation of

Strategies to Improve the Corporate Social Responsibility Performance in Food and Pharmaceutical Industries: Empirical Evidence from Iran. Sustainability 2021, 13, 12569. https:// doi.org/10.3390/su132212569

Academic Editor: Andrea Pérez

Received: 16 October 2021

Accepted: 11 November 2021

Published: 14 November 2021

Publisher's Note: MDPI stays neutral with regard to jurisdictional claims in published maps and institutional affiliations.

Copyright: (c) 2021 by the authors. Licensee MDPI, Basel, Switzerland. This article is an open access article distributed under the terms and conditions of the Creative Commons Attribution (CC BY) license (https:// creativecommons.org/licenses/by/ $4.0 /)$.
Abstract: Since there is a lack of a strong CSR platform in the Iranian corporate environment, especially in the food and pharmaceutical industries, the proposed and existing strategies can be utilized to empower employees and the general public, improve executive processes, improve quality and customer satisfaction, and finally, organize financial and accounting reports. Hence, this study seeks to determine and evaluate strategies to improve the concepts and domain of corporate social responsibility (CSR) of food and pharmaceutical industries in Iran based on the requirements of sustainable development theory. This study analyzes the data of 22 companies active in the food and pharmaceutical industries listed on the Tehran Stock Exchange (TSE) over a period of six years (2014-2019). Eighty-three indicators were used to evaluate the performance of social responsibility based on economic, social and environmental dimensions. The Pareto approach has been used to determine the most important unmet current requirements. Then, using the Delphi method and content validity, appropriate strategies were determined. Finally, a correlation matrix was used to determine the most important and comprehensive strategies. Findings showed that 14 requirements in the field of corporate social responsibility are of great importance and with six strategies, the necessary measures to meet those requirements can be covered.

Keywords: corporate social responsibility; sustainable development; performance improvement strategies; pareto approach; delphi method

\section{Introduction}

While governments have traditionally been solely responsible for improving the living conditions of the people, societies need more than what governments can afford. In this regard, the focus is shifting from governments to the role of the economic activities of individuals and companies in society, and is focused on businesses. Progressive companies seek to differentiate themselves from others in terms of engagement and attention to social responsibility [1].

The emergence of the concept of corporate social responsibility (CSR) in the economic, scientific and political circles of the world in recent decades can be attributed to the more complex business environment, globalization of the economy and the emergence 
of multinational corporations, the demand for business transparency, political pressures of governments, emergence of social and environmental crises, etc. [2]. In today's world, companies, especially those operating in global markets, in addition to maximizing the value of investors' stocks, are increasingly required to strike a balance between the social, economic and environmental elements of their business. They must apply socially, ethically, legally and environmentally responsible standards in their business. Therefore, corporate sustainability has always been a key issue which includes all activities related to production and economic growth.

When a company adheres to its CSRs, it can disclose this to inform stakeholders. A sustainability report is published by a company or organization on the economic, environmental, and social impacts of its day-to-day operations, reflecting the values and governance model of the organization and the relationship between the organization's strategies and its commitment to a sustainable global economy. Sustainability reporting represents non-financial issues that have been highly regarded by investors and policymakers in recent years because the disclosure of none-financial information alongside financial disclosure affects the sustainable performance of companies in the long run [3-5].

Dimensions of CSR in Iran, like many developing countries, impose significant costs on the company from outside, or have a significant impact on corporate profitability. Considering that pharmaceutical and food companies are one of the most strategic industries in the country, the expansion and capability in this field can significantly improve the country's position in the region and on a international level. Companies operating in this field deal with the most basic levels of human needs, namely physiological needs, and security, while a wide range of stakeholders benefit from their diverse products and services.

The important point is that the indicators and criteria for disclosing the social dimension of corporate responsibility are some general guidelines and mainly measure one or more social components, not all of them. Moreover, since these indicators mostly depend on cultural, political, legal, social, and economic contexts the authors of the article seek to provide strategies to improve these indicators in a comprehensive manner with emphasis on Iran's corporate environment and with consideration for their ability to measure and disclose. The main contribution is the novelty of such a study in these industries since such a comprehensive study has been never conducted to determine CSR and evaluate them within the Iranian food and pharmaceutical environment. As a result, the contribution of this study is to provide the requirements for these two important industries in terms of performance sustainability and measurement of CSR fulfillment. This research and its results can be an effective step to create the necessary knowledge, understanding and motivation for Iranian managers and regulators to pay attention to CSR and to include this category in the purposes of reporting and voluntary or mandatory disclosure of companies to stakeholders with a view to sustainable development in society.

\section{Theoretical Foundations}

\subsection{Three Main Components of Corporate Social Responsibility (CSR)}

The first conceptual basis of CSR was introduced in the early 1950s [6]. The main characteristic of social responsibility is the desire of an organization to be responsible and accountable for the consequences of its activities and decisions upon society and the environment. Social responsibility, first of all, introduces the framework of moral governance according to which organizations take strategies that improve the conditions of society and avoid activities that make the situation of society worse. In general, the term corporate social responsibility refers to the emergence of a movement that seeks to incorporate environmental and social factors into corporate business decisions, business strategy and accounting to increase social and environmental performance alongside economics for the business unit, community and environment [7].

In dividing the components of social responsibility, we have identified three pillars: economic, social and environmental [8], so that the CSR assessment can be done by three areas: the interests of shareholders and employees, social and public interests, and 
environmental considerations. Shareholders' approach focuses on improving financial performance, reducing operating costs, enhancing the company name, increasing sales and customer trust, increasing productivity and higher quality production or service, reducing the need for new regulations, access to capital, improving product safety and reducing the need for new guarantees [9-13]. In the interests of society and the people, participation in public welfare, voluntary staffing, participation in public education, employment and homelessness programs, and product safety and quality are considered.

Naturally, the relevant strategies and goals can be identified in the three mentioned areas and appropriate programs can be developed in this regard. Many organizations have gone beyond this and have not only been content with cross-cutting measures, but also follow specific strategies in this regard, such as how to interact with the government, the implementation of legal and ethical responsibilities, as well as technical implications and pursue economics such as firm efficiency and commitment to market economy mechanisms [14]. The impact of implementing social responsibility strategies in some reports goes beyond finance and customers, as it has been said that it leads to the development of learning capabilities which in turn leads to organizational innovation $[15,16]$.

Social responsibility activities include the inclusion of social requirements in the final product or service providing process, such as the production of products using environmentally friendly technologies [17]. Additionally, changing the method of human resource management is another activity and action in this field, for example, the delegation of authority to employees. Achieving higher levels of environmental efficiency through recycling and pollution reduction is also one of the activities and measures related to corporate social responsibility, which, for example, can be considered a decisive position in reducing environmental pollution in this context [18].

\subsection{Performance Evaluation and Improvement Measures}

Performance evaluation is one of the approaches that is always used to make decisions about economic units also for investment [19]. Determining the appropriate criteria and then adopting the method of evaluation, analysis and determining the necessary measures to improve the situation are among the challenges of performance evaluation in each area.

Performance evaluation is the process of measuring and evaluating performance in companies within the framework of scientific principles and concepts of management to fulfill organizational goals and tasks in the form of executive plans [20]. In other words, performance appraisal is done to assess the extent to which the expectations of various stakeholders, including managers, employees, shareholders, government and citizens, are met. Therefore, performance evaluation, while looking forward to achieving the intended goals, can also look back. In order to determine and take the necessary measures to correct the complications and failures.

Performance covers a wide range from the organization's environment to the details of the process and the behavior of managers and employees. Social performance itself is another manifestation of an organization's performance. Social performance itself is another manifestation of an organization's performance. The company's social performance can provide much more accurate results than the company's overall performance, given social and environmental issues [21]. Therefore, diagnosis or cognition helps the organization to understand its current function and to discover the factors influencing its progress.

Designing a change program and implementing it is a prerequisite for moving towards a better situation. Organizational transformation is a planned activity or endeavor that is managed throughout the organization by the organization's top management and increases the effectiveness of the organization through a planned change in executive processes. Organizational transformation is a response to change and a complex educational strategy to change the beliefs, attitudes and values and structure of the organization to ensure these factors can better adapt to new technology, markets and challenges, as well as the speed of change in conditions and environment. 


\subsection{Theoretical Relationship between the Social Responsibility and Performance}

Adopting the principles of social responsibility for organizations is costly. These costs may include purchasing new equipment that is less harmful to the environment, changing management structures, or establishing stricter quality controls. The benefits of adopting the principles of social responsibility for organizations are: brand promotion and credit enhancement, the possibility of attracting more capital resources due to high business reputation, reducing the risk of accidents and tragic events, improving the working environment and thus improving productivity and increasing the ability to recruit and retain staff, leading to reduced mobility, absenteeism and training costs [22-25]. Most experts believe that social responsibility costs are short-term, and its benefits are often long-term [26]. Social responsibility is a kind of investment for the future in the hope of gaining a sustainable and long-term competitive advantage.

Senior executives with short-term vision do not bear the short-term costs of social responsibility [27]. Conversely, managers who have a long-term vision are willing to spend to improve the welfare of society, solve social problems, environmental pollution, improve working conditions, respect human rights, participate in public welfare, etc. [28], so that in the long run, they can benefit from social progress and, on the other hand, gain prestige and fame for themselves in society and among their customers and stakeholders [29].

Bassen et al. (2006), studied the relationship between corporate social responsibility and corporate financial performance and concluded that companies with higher social performance have lower risk as well as cost [30]. Corporate capital decreases with increasing social performance. Kangarloui and Bayazidi (2010) examined the relationship between social responsibility and organizational commitment with conservatism in financial reporting of companies listed on the TSE. Findings indicate that the relationship between corporate social responsibility and organizational commitment and conservatism is positive [31]. However, the relationship between corporate social responsibility and conservatism is statistically significant.

Cheah et al. (2007) investigated the effect of pharmaceutical product recalls by pharmaceutical companies in the United Kingdom (U.K.) and the United States (U.S.) [32]. Their analysis revealed that while U.K. investors rewarded product recalls by firms which were not usually CSR-active, U.S investors punished non-CSR active firms that performed recalls. Such differences can be challenging for companies working in both countries.

Considering the fact that both countries are using the same corporate governance system, such result will show how different cultures can have different effects on the results of CSR policies, which is one of the motivations of our study.

\section{Research Methods}

The present research is applied in terms of purpose and descriptive and analytical in terms of method and nature. Since the research focuses on companies active in the field of food and pharmaceutical production, it is also a case study. The statistical population of this research is 22 companies active in food and pharmaceutical industries listed on the Tehran Stock Exchange (TSE) over a period of six years (2014-2019). They are the only companies in these industries which follow the CSR codes of Iran which observed by the TSE.

Based on the survey conducted through interviews with experts of the organizations, review of missions, goals and tasks of the companies under review, as well as library documents including previous studies and research. Finally, 83 indicators were identified, and the status of these companies evaluated as following three steps:

i. First, using the Pareto Principle, the most important insufficient requirements were identified. Based on the Pareto Principle, 80 percent of the output is attributable to 20 percent of its input which in this study is about the requirements' significance.

ii. Then, using the opinions of experts, the most important appropriate strategies to improve the situation were identified through the Delphi and content validity methods. The main reasons for choosing the Delphi method are its capabilities in ex- 
tracting accurate information that is unavailable, easing the judgmental analysis in complicated problems, dealing with problems where there is disagreement in the hypothesis, and determining the concerns and assessing the uncertainty in quantitative manner [33-36].

iii. Finally, using the correlation matrix [37], the most important strategies were identified. To show the dependencies between the requirements, a triangular-shaped relationship matrix over the primary relationship matrix to display correlations between requirements is used. To further interrogate this problem, recommended normalization transforms [8] on the relationship values in the relationship matrix $R$ using Equation (1), resulting in a relative demanded weights according to their significance.

$$
R_{i j}^{n}=R_{i, j} /\left\{\sum_{j=1}^{n} R_{i j}\right\}
$$

where $R_{i j}$ is qualified relationship between the requirements and $i$ is requirement and $j$ is the strategies.

The experts are ten individuals consisting of six expert accountants and auditors who have worked in these industries in Iran, as well as four professors from Iranian universities and scientific centers in the field of finance and accounting, who participated in all stages of the research. The authors tried to use these experts since they were more aware of Iranian corporate environment.

\section{Results}

\subsection{Evaluating the CSR Performance}

In the first step, the weights of the criteria for evaluating the CSR performance as well as the performance of food and pharmaceutical companies regarding the mentioned criteria were extracted by reviewing the literature. To obtain this data, the requirements met by only less than five percent of companies were eliminated. Then, the weighted gap, by subtracting from the optimum value of 22 , and the relative and cumulative weighted gap calculated. Those requirements that accounted for $80 \%$ of the cumulative gap were selected (highlighted gray in Table 1) as traceable requirements for investigation, as shown in Table 1. The final significance of each requirement was calculated and rounded based on the weight of the selected requirements.

Table 1. Data on requirements for disclosing the CSR performance for food and pharmaceutical companies.

\begin{tabular}{|c|c|c|c|c|c|}
\hline Factor & Obligation to Disclosure & $\begin{array}{l}\text { Weighted } \\
\text { Gap }\end{array}$ & $\begin{array}{c}\text { Relative } \\
\text { Gap }\end{array}$ & $\begin{array}{c}\text { Cumulative } \\
\text { Gap }\end{array}$ & $\begin{array}{c}\text { Final } \\
\text { Significant }\end{array}$ \\
\hline Market presence & Free cash flow & 125.13 & 17.74 & 17.74 & 10 \\
\hline Economic effects & $\begin{array}{c}\text { Identifying and describing important indirect } \\
\text { economic effects such as foreign exchange } \\
\text { savings, etc. }\end{array}$ & 57.99 & 8.22 & 25.96 & 6 \\
\hline investment & Costs and social investment by type and scope & 57.88 & 8.21 & 34.16 & 2 \\
\hline Market presence & $\begin{array}{l}\text { Trends and changes in technology and } \\
\text { regulations affecting on markets and products in } \\
\text { the region or local environment }\end{array}$ & 56.72 & 8.04 & 42.2 & 2 \\
\hline investment & $\begin{array}{l}\text { Investment in infrastructure and public services } \\
\text { (bridge, road, park) to participate in regional and } \\
\text { local development }\end{array}$ & 55.56 & 7.88 & 50.08 & 22 \\
\hline investment & $\begin{array}{l}\text { Costs and environmental investment by type } \\
\text { and scope }\end{array}$ & 37.1 & 5.26 & 55.34 & 10 \\
\hline
\end{tabular}


Table 1. Cont.

\begin{tabular}{|c|c|c|c|c|c|}
\hline Factor & Obligation to Disclosure & $\begin{array}{l}\text { Weighted } \\
\text { Gap }\end{array}$ & $\begin{array}{l}\text { Relative } \\
\text { Gap }\end{array}$ & $\begin{array}{l}\text { Cumulative } \\
\text { Gap }\end{array}$ & $\begin{array}{c}\text { Final } \\
\text { Significant }\end{array}$ \\
\hline Economic effects & $\begin{array}{l}\text { Changes in the market and competitors in the } \\
\text { industry and region (advantages and } \\
\text { competitive pressure) and its perspective }\end{array}$ & 30.64 & 4.34 & 59.68 & 5 \\
\hline Taxation & $\begin{array}{l}\text { Obligatory taxes and other duties Paid } \\
\text { by company }\end{array}$ & 29.43 & 4.17 & 63.85 & 2 \\
\hline investment & $\begin{array}{l}\text { Financial costs for climate change (reduction of } \\
\text { climate pollution, etc.) }\end{array}$ & 27.45 & 3.89 & 67.74 & 10 \\
\hline Market presence & $\begin{array}{c}\text { Trend and changes in quantity/monetary of } \\
\text { sales according to } \\
\text { products/region/customers, etc. }\end{array}$ & 25.69 & 3.64 & 71.39 & 10 \\
\hline Taxation & Performance tax paid by the company & 23.2 & 3.29 & 74.68 & 7 \\
\hline supply chain & $\begin{array}{l}\text { Policies and systems for consumers health and } \\
\text { consumers protection }\end{array}$ & 12.11 & 1.72 & 76.39 & 5 \\
\hline $\begin{array}{l}\text { Variation of } \\
\text { resources }\end{array}$ & $\begin{array}{l}\text { Reducing the destructive effects on biodiversity } \\
\text { and its various species and natural resources } \\
\text { such as forests, soils, etc. }\end{array}$ & 11.81 & 1.67 & 78.07 & 5 \\
\hline Employment & $\begin{array}{l}\text { Participating in planning and providing training } \\
\text { to train and develop new workforce }\end{array}$ & 10.76 & 1.52 & 79.59 & 4 \\
\hline $\begin{array}{l}\text { Variation of } \\
\text { resources }\end{array}$ & $\begin{array}{c}\text { Strategies, current actions and future plans to } \\
\text { manage impacts on biodiversity and } \\
\text { natural resources }\end{array}$ & 9.85 & 1.4 & 80.99 & - \\
\hline Corruption & $\begin{array}{l}\text { Voluntary rules, regulations and principles } \\
\text { relating to communications, industrial relations, } \\
\text { marketing, and advertising. }\end{array}$ & 8.81 & 1.25 & 82.23 & - \\
\hline Employment & $\begin{array}{l}\text { Processes and policies for communicating with } \\
\text { company employees and surveying employees } \\
\text { and reviewing its results in the } \\
\text { company environment }\end{array}$ & 8.62 & 1.22 & 83.46 & - \\
\hline supply chain & $\begin{array}{l}\text { Awards or certificates of quality/observance of } \\
\text { consumer rights, etc. }\end{array}$ & 8.59 & 1.22 & 84.67 & - \\
\hline participation & CSR goals, programs and plans & 7.84 & 1.11 & 85.78 & - \\
\hline Ethics & Ethical/Responsive Advertising and Marketing & 7.72 & 1.09 & 86.88 & - \\
\hline Emission & $\begin{array}{c}\text { Obvious effects of wastewater from the } \\
\text { company's operations on water and } \\
\text { soil resources }\end{array}$ & 7.54 & 1.07 & 87.95 & - \\
\hline Ethics & $\begin{array}{l}\text { Ethical/responsible competition and pricing } \\
\text { (constructive relationship with competitors and } \\
\text { respect for their rights) }\end{array}$ & 7.09 & 1 & 88.95 & - \\
\hline Employment & $\begin{array}{l}\text { Describing training programs to inform staff } \\
\text { about addiction, AIDS, hepatitis, etc. }\end{array}$ & 6.83 & 0.97 & 89.92 & - \\
\hline participation & $\begin{array}{c}\text { Consumption resources/cash grants, products } \\
\text { and services to support social, educational, } \\
\text { upbringing and artistic activities }\end{array}$ & 6.73 & 0.95 & 90.87 & - \\
\hline participation & Special Committee or Independent CSR Unit & 6.41 & 0.91 & 91.78 & - \\
\hline Employment & $\begin{array}{c}\text { Description and explanation of criteria and } \\
\text { activities of health and safety and occupational } \\
\text { health of employees and observance of health } \\
\text { laws and occupational safety and } \\
\text { health standards }\end{array}$ & 6.26 & 0.89 & 92.67 & - \\
\hline
\end{tabular}


Table 1. Cont.

\begin{tabular}{|c|c|c|c|c|c|}
\hline Factor & Obligation to Disclosure & $\begin{array}{l}\text { Weighted } \\
\text { Gap }\end{array}$ & $\begin{array}{l}\text { Relative } \\
\text { Gap }\end{array}$ & $\begin{array}{l}\text { Cumulative } \\
\text { Gap }\end{array}$ & $\begin{array}{c}\text { Final } \\
\text { Significant }\end{array}$ \\
\hline participation & $\begin{array}{l}\text { Customer satisfaction management systems and } \\
\text { actions related to customer satisfaction }\end{array}$ & 6.19 & 0.88 & 93.55 & - \\
\hline Ethics & Business ethics training & 6.09 & 0.86 & 94.41 & - \\
\hline Raw material & $\begin{array}{l}\text { Actions and initiatives intended to provide } \\
\text { products and services based on recyclable } \\
\text { materials and reduce energy consumption }\end{array}$ & 5.19 & 0.74 & 95.15 & - \\
\hline Ethics & $\begin{array}{l}\text { Sponsorship of educational conferences, } \\
\text { seminars and art exhibitions }\end{array}$ & 4.81 & 0.68 & 95.83 & - \\
\hline participation & $\begin{array}{l}\text { Awards and certificates received related to social, } \\
\text { cultural, environmental, educational and } \\
\text { sports activities }\end{array}$ & 4.73 & 0.67 & 96.5 & - \\
\hline Raw material & $\begin{array}{l}\text { Water used, recycled and treated according to } \\
\text { the source and how it is consumed }\end{array}$ & 4.62 & 0.66 & 97.15 & - \\
\hline Ethics & Company code and its ethical and social charter & 4.41 & 0.62 & 97.78 & - \\
\hline Products & $\begin{array}{l}\text { Procedures for how reducing high-risk and } \\
\text { non-hazardous waste and proper waste disposal } \\
\text { with respect to environmental issues }\end{array}$ & 4.03 & 0.57 & 98.35 & - \\
\hline Human rights & $\begin{array}{c}\text { Employee welfare activities (workers 'house } \\
\text { plan, workers' welfare fund and life } \\
\text { insurance, etc.) }\end{array}$ & 3.77 & 0.53 & 98.88 & - \\
\hline Employment & $\begin{array}{l}\text { Description of activities and training hours and } \\
\text { the number and percentage of trained staff based } \\
\text { on classes and groups. }\end{array}$ & 3.42 & 0.48 & 99.37 & - \\
\hline Raw material & $\begin{array}{l}\text { The amount and value of raw materials } \\
\text { consumed directly and indirectly }\end{array}$ & 2.65 & 0.38 & 99.74 & - \\
\hline Employment & $\begin{array}{l}\text { Total staff by type of occupation, age group, } \\
\text { geographical area, gender, etc. }\end{array}$ & 1.8 & 0.26 & 100 & - \\
\hline $\begin{array}{l}\text { Economic } \\
\text { performance }\end{array}$ & $\begin{array}{l}\text { Coverage of goals and requirements defined in } \\
\text { company planning }\end{array}$ & 0 & 0 & 100 & - \\
\hline
\end{tabular}

\subsection{Content Validity}

Content validity ratio (CVR) and content validity index (CVI) calculated using Equations (2) and (3), respectively.

$$
\begin{gathered}
C V R=\frac{\text { Number of experts indicating "essential" }-\frac{\text { Total number of experts }}{2}}{\frac{\text { Total number of experts }}{2}} \\
C V I=\frac{\text { Number of experts rating the item } 3 \text { or } 4}{\text { Total number of experts }}
\end{gathered}
$$

Items for which the calculated CVR is less than the numeric value determined by Lawshe Table, should be eliminated. The CVR should be at least 0.6 and the minimum CVI should be 0.79 . Accordingly, 31 strategies were proposed and, finally, by applying CVR and CVI indicators, 20 strategies were selected for the next stage. Table 2 shows the most important strategies in fulfilling the requirement of disclosure of CSR performance using the heatmap in a way that the darker color illustrates the higher value. 
Table 2. The most important strategies in fulfilling the requirements of disclosure of CSR performance.

\begin{tabular}{|c|c|c|c|c|c|c|c|c|c|c|c|c|c|c|}
\hline \multirow[b]{2}{*}{ Strategy } & \multicolumn{3}{|c|}{ Significance } & \multicolumn{3}{|c|}{ Relevance } & \multicolumn{5}{|c|}{ Clarity } & \multirow[b]{2}{*}{ CVR } & \multirow[b]{2}{*}{ CVI1 } & \multirow[b]{2}{*}{ CVI2 } \\
\hline & 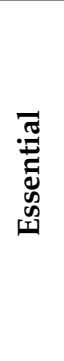 & 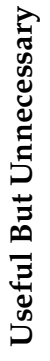 & 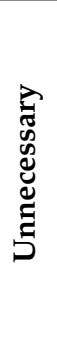 & 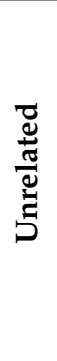 & 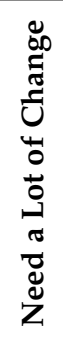 & 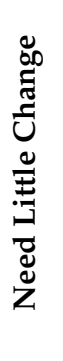 & 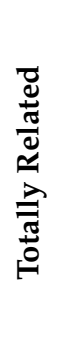 & 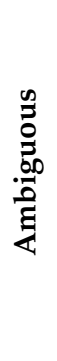 & 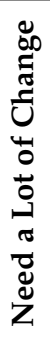 & 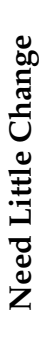 & $\stackrel{\Xi}{\circlearrowright}$ & & & \\
\hline Learning new business technology by human resources & 9 & 1 & 0 & 0 & 1 & 1 & 8 & 0 & 0 & 1 & 9 & 0.8 & 0.9 & 1 \\
\hline Employee flexibility in business related skills & 10 & 0 & 0 & 0 & 0 & 1 & 9 & 0 & 0 & 0 & 10 & 1 & 1 & 1 \\
\hline Providing non-profit support in the fields of education, health and welfare & 9 & 1 & 0 & 0 & 1 & 1 & 8 & 0 & 2 & 1 & 7 & 0.8 & 0.9 & 0.8 \\
\hline $\begin{array}{l}\text { Increasing the quantitative level of employment and supporting the livelihood } \\
\text { of employees }\end{array}$ & 9 & 0 & 1 & 0 & 1 & 1 & 8 & 0 & 2 & 1 & 7 & 0.8 & 0.9 & 0.8 \\
\hline Timely payment of duties and taxes & 10 & 0 & 0 & 0 & 0 & 0 & 10 & 0 & 0 & 0 & 10 & 1 & 1 & 1 \\
\hline $\begin{array}{l}\text { Participating with the government in carrying out civil works and reconstructing the } \\
\text { destructive effects left over from the company's activities }\end{array}$ & 9 & 1 & 0 & 0 & 1 & 1 & 8 & 0 & 0 & 1 & 9 & 0.8 & 0.9 & 1 \\
\hline Recycling of waste from the company's business cycle & 10 & 0 & 0 & 0 & 0 & 0 & 10 & 0 & 0 & 0 & 10 & 1 & 1 & 1 \\
\hline Recycling of natural resources consumed in the company's business cycle & 10 & 0 & 0 & 0 & 0 & 0 & 10 & 0 & 0 & 0 & 10 & 1 & 1 & 1 \\
\hline Production of organic and health-oriented products & 9 & 1 & 0 & 0 & 1 & 2 & 7 & 0 & 3 & 1 & 6 & 0.8 & 0.9 & 0.7 \\
\hline $\begin{array}{l}\text { Maintaining quality and make prices competitive by reducing the cost of products in order } \\
\text { to maintain market share }\end{array}$ & 8 & 1 & 1 & 0 & 1 & 1 & 8 & 0 & 2 & 1 & 7 & 0.6 & 0.9 & 0.8 \\
\hline Paying attention to all stages of the value chain to increase customer satisfaction & 9 & 1 & 0 & 0 & 0 & 2 & 8 & 0 & 0 & 1 & 9 & 0.8 & 1 & 1 \\
\hline Creating added value through conversion industries and reducing raw material sales & 9 & 1 & 0 & 0 & 0 & 2 & 8 & 2 & 1 & 1 & 6 & 0.8 & 1 & 0.7 \\
\hline Adherence to the commitments and promises made in product advertising & 8 & 1 & 1 & 1 & 1 & 2 & 6 & 0 & 2 & 1 & 7 & 0.6 & 0.8 & 0.8 \\
\hline Investing to improve product quality instead of spending on product upgrades & 8 & 1 & 1 & 0 & 1 & 2 & 6 & 0 & 2 & 1 & 7 & 0.6 & 0.89 & 0.8 \\
\hline Participating in charitable projects and help alleviate poverty in the production area & 10 & 0 & 0 & 0 & 0 & 1 & 9 & 0 & 0 & 1 & 9 & 1 & 1 & 1 \\
\hline Compensation of pollution in natural resources and long-term investment to compensate & 10 & 0 & 0 & 0 & 0 & 2 & 8 & 0 & 0 & 1 & 9 & 1 & 1 & 1 \\
\hline Active participation in government programs and projects that support nature & 9 & 1 & 0 & 0 & 1 & 1 & 8 & 0 & 2 & 1 & 7 & 0.8 & 0.9 & 0.8 \\
\hline
\end{tabular}


Table 2. Cont.

\begin{tabular}{|c|c|c|c|c|c|c|c|c|c|c|c|c|c|c|}
\hline \multirow[b]{2}{*}{ Strategy } & \multicolumn{3}{|c|}{ Significance } & \multicolumn{3}{|c|}{ Relevance } & \multicolumn{5}{|c|}{ Clarity } & \multirow[b]{2}{*}{ CVR } & \multirow[b]{2}{*}{ CVI1 } & \multirow[b]{2}{*}{ CVI2 } \\
\hline & 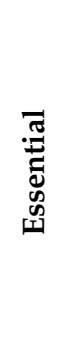 & 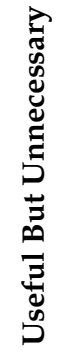 & 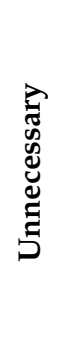 & 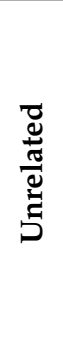 & 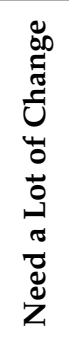 & 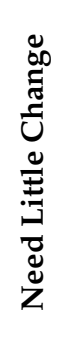 & 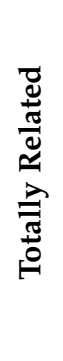 & 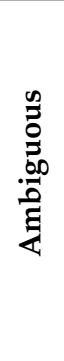 & 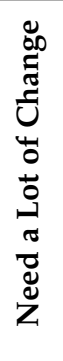 & 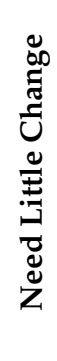 & 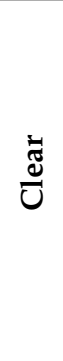 & & & \\
\hline $\begin{array}{l}\text { Transparent reporting of financial statements and acceptance of voluntary auditing of } \\
\text { financial statements if no audit services are required }\end{array}$ & 10 & 0 & 0 & 0 & 0 & 1 & 9 & 0 & 0 & 0 & 10 & 1 & 1 & 1 \\
\hline $\begin{array}{c}\text { Participating in government tax programs to prevent government dependence on oil and } \\
\text { natural resources }\end{array}$ & 10 & 0 & 0 & 0 & 0 & 1 & 9 & 0 & 0 & 0 & 10 & 1 & 1 & 1 \\
\hline $\begin{array}{l}\text { Investing in companies that produce raw materials to ensure the entry of those materials } \\
\text { into the company }\end{array}$ & 9 & 1 & 0 & 0 & 1 & 1 & 8 & 0 & 1 & 1 & 8 & 0.8 & 0.9 & 0.9 \\
\hline
\end{tabular}




\subsection{Correlation Matrix}

In this step, the selected strategies were combined, and similar or duplicate cases were eliminated. Arbitrary scales can be used to determine the correlation in order to perform a subjective selection of items. In this research the following scale is used:

$0=$ without any correlation

$1=$ low correlation

$3=$ High correlation

$9=$ Very high correlation

Considering that the opinions of ten experts have been used to complete the constructs of these matrices, the correlation coefficient of each construct is calculated and rounded using the arithmetic mean.

The correlation between the proposed strategies in fulfilling the requirements of CSR disclosure and between the requirements of disclosure of CSR performance are shown in Tables 3 and 4, respectively. For a better understanding, this table is illustrated using the heatmap in order to make it more understandable.

Therefore, the correlation matrix between disclosure requirements and strategies is adjusted in Table 5. Eventually, the final significance of strategies is shown in Table 6. The first six strategies which have the highest significance are highlighted. According to Wasserman (2003) [37] $R_{i j}^{\text {norm }}$, shows the degree of costumer requirement (i) fulfillment and, $j$ shows fulfillment of level of $x_{j}$. Therefore, $x_{j}$ as decision variable is from 0 to 1 , where 1 shows the complete fulfillment the requirement. As can be seen, the six strategies have about $74 \%$ impact on the fulfillment of the requirements related to the performance of CSR. Therefore, they can be considered as superior strategies.

Table 3. Correlation between the proposed strategies in fulfilling the requirements of disclosure of CSR performance.

\begin{tabular}{|c|c|c|c|c|c|c|c|c|c|}
\hline Strategy & 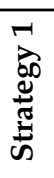 & 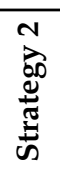 & 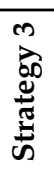 & 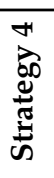 & 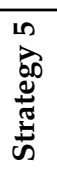 & 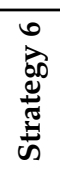 & 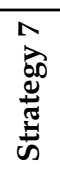 & 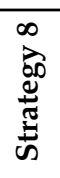 & 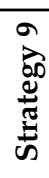 \\
\hline Employee flexibility in business related skills & 9 & & & & & & & & \\
\hline Providing non-profit support in the fields of education, health and welfare & 2 & 9 & & & & & & & \\
\hline $\begin{array}{c}\text { Increasing the quantitative level of employment and supporting the } \\
\text { livelihood of employees }\end{array}$ & 4 & 2 & 9 & & & & & & \\
\hline Timely payment of duties and taxes & 2 & 2 & 1 & 9 & & & & & \\
\hline Recycling of waste from the company's business cycle & 3 & 5 & 1 & 1 & 9 & & & & \\
\hline Production of organic and health-oriented products & 3 & 2 & 2 & 1 & 3 & 9 & & & \\
\hline $\begin{array}{c}\text { Maintaining quality and make prices competitive by reducing the cost of } \\
\text { products in order to maintain market share }\end{array}$ & 5 & 2 & 1 & 1 & 1 & 1 & 9 & & \\
\hline $\begin{array}{l}\text { Paying attention to all stages of the value chain to increase } \\
\text { customer satisfaction }\end{array}$ & 4 & 2 & 1 & 2 & 2 & 4 & 7 & 9 & \\
\hline $\begin{array}{l}\text { Transparent reporting of financial statements and acceptance of voluntary } \\
\text { auditing of financial statements if no audit services are required }\end{array}$ & 3 & 2 & 1 & 5 & 1 & 1 & 1 & 1 & 9 \\
\hline
\end{tabular}


Table 4. Correlation between requirements of CSR performance disclosure.

\begin{tabular}{|c|c|c|c|c|c|c|c|c|c|}
\hline Obligation to Disclosure & 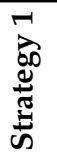 & 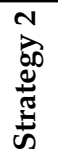 & 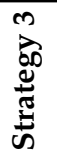 & 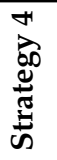 & 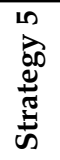 & 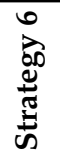 & 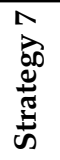 & 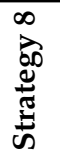 & 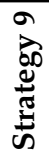 \\
\hline Free cash flow & 1 & 1 & 3 & 4 & 2 & 2 & 5 & 5 & 4 \\
\hline $\begin{array}{l}\text { Identifying and describing important indirect economic effects such as } \\
\text { foreign exchange savings and ... }\end{array}$ & 1 & 2 & 2 & 2 & 2 & 2 & 6 & 4 & 2 \\
\hline Costs and social investment by type and scope & 3 & 5 & 4 & 2 & 5 & 3 & 5 & 3 & 6 \\
\hline $\begin{array}{l}\text { Trends and changes in technology and regulations affecting on markets and } \\
\text { products in the region or local environment }\end{array}$ & 7 & 1 & 3 & 1 & 1 & 1 & 7 & 7 & 1 \\
\hline $\begin{array}{l}\text { Investment in infrastructure and public services (bridge, road, park) to } \\
\text { participate in regional and local development }\end{array}$ & 1 & 9 & 2 & 2 & 2 & 1 & 1 & 1 & 1 \\
\hline Costs and environmental investment by type and scope & 3 & 7 & 2 & 1 & 8 & 1 & 1 & 1 & 1 \\
\hline $\begin{array}{l}\text { Changes in the market and competitors in the industry and region } \\
\text { (advantages and competitive pressure) and its perspective }\end{array}$ & 7 & 1 & 2 & 1 & 1 & 2 & 6 & 6 & 1 \\
\hline Obligatory taxes and other duties Paid by company & 1 & 1 & 1 & 9 & 1 & 1 & 1 & 1 & 8 \\
\hline Financial costs for climate change (reduction of climate pollution, etc.) & 2 & 3 & 1 & 1 & 2 & 1 & 1 & 1 & 6 \\
\hline $\begin{array}{l}\text { Trend and changes in quantity/monetary of sales according to } \\
\text { products/region/customers, etc. }\end{array}$ & 4 & 1 & 1 & 1 & 1 & 2 & 6 & 5 & 4 \\
\hline Performance tax paid by the company & 1 & 2 & 2 & 9 & 2 & 1 & 2 & 2 & 9 \\
\hline Policies and systems for consumers health and consumers protection & 2 & 3 & 2 & 1 & 3 & 9 & 2 & 2 & 1 \\
\hline $\begin{array}{l}\text { Reducing the destructive effects on biodiversity and its various species and } \\
\text { natural resources such as forests, soils, etc. }\end{array}$ & 2 & 3 & 1 & 1 & 9 & 4 & 1 & 1 & 1 \\
\hline $\begin{array}{l}\text { Participating in planning and providing training to train and develop } \\
\text { new workforce }\end{array}$ & 9 & 5 & 3 & 1 & 1 & 2 & 4 & 4 & 1 \\
\hline
\end{tabular}

Table 5. Adjusted correlation between requirements for disclosure of CSR performance.

\begin{tabular}{|c|c|c|c|c|c|c|c|c|c|c|}
\hline Obligation to disclosure & 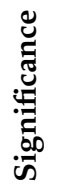 & 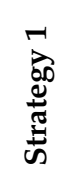 & के & 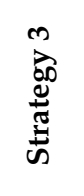 & 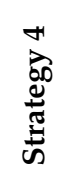 & 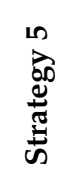 & 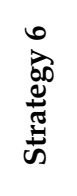 & के & 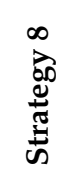 & 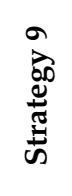 \\
\hline Free cash flow & 10 & 0.01 & 0.01 & 0.01 & 0.01 & 0.01 & 0.01 & 0.01 & 0.01 & 0.01 \\
\hline $\begin{array}{l}\text { Identifying and describing important indirect } \\
\text { economic effects such as foreign exchange savings, etc. }\end{array}$ & 6 & 0.01 & 0.01 & 0 & 0.01 & 0.01 & 0.01 & 0.01 & 0.01 & 0.01 \\
\hline Costs and social investment by type and scope & 2 & 0.01 & 0.01 & 0.01 & 0.01 & 0.01 & 0.01 & 0.01 & 0.01 & 0.01 \\
\hline $\begin{array}{l}\text { Trends and changes in technology and regulations } \\
\text { affecting on markets and products in the region or } \\
\text { local environment }\end{array}$ & 2 & 0.02 & 0.01 & 0.01 & 0.01 & 0.01 & 0.01 & 0.02 & 0.02 & 0.01 \\
\hline $\begin{array}{c}\text { Investment in infrastructure and public services } \\
\text { (bridge, road, park) to participate in regional and } \\
\text { local development }\end{array}$ & 22 & 0.01 & 0.01 & 0 & 0 & 0.01 & 0 & 0 & 0.01 & 0 \\
\hline Costs and environmental investment by type and scope & 10 & 0.01 & 0.01 & 0.01 & 0 & 0.01 & 0.01 & 0.01 & 0.01 & 0 \\
\hline $\begin{array}{l}\text { Changes in the market and competitors in the industry } \\
\text { and region (advantages and competitive pressure) and } \\
\text { its perspective }\end{array}$ & 5 & 0.01 & 0.01 & 0.01 & 0.01 & 0.01 & 0.01 & 0.01 & 0.01 & 0.01 \\
\hline Obligatory taxes and other duties Paid by company & 2 & 0.01 & 0.01 & 0 & 0.01 & 0 & 0 & 0 & 0.01 & 0.01 \\
\hline $\begin{array}{l}\text { Financial costs for climate change (reduction of climate } \\
\text { pollution, etc.) }\end{array}$ & 10 & 0.01 & 0.01 & 0 & 0.01 & 0.01 & 0 & 0 & 0 & 0.01 \\
\hline
\end{tabular}


Table 5. Cont.

\begin{tabular}{|c|c|c|c|c|c|c|c|c|c|c|}
\hline Obligation to disclosure & 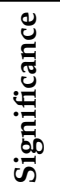 & 离 & $\begin{array}{l}N \\
\stackrel{\infty}{\infty} \\
\stackrel{\pi}{\pi} \\
\omega\end{array}$ & 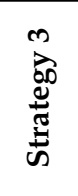 & 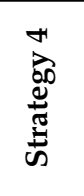 & 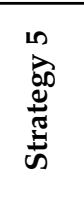 & 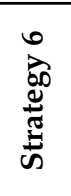 & 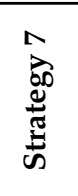 & 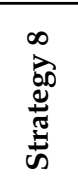 & 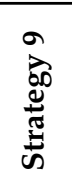 \\
\hline $\begin{array}{l}\text { Trend and changes in quantity/monetary of sales } \\
\text { according to products/region/customers etc. }\end{array}$ & 10 & 0.01 & 0.01 & 0 & 0.01 & 0.01 & 0.01 & 0.01 & 0.01 & 0.01 \\
\hline Performance tax paid by the company & 7 & 0.01 & 0.01 & 0.01 & 0.01 & 0.01 & 0.01 & 0.01 & 0.01 & 0.01 \\
\hline $\begin{array}{l}\text { Policies and systems for consumers health and } \\
\text { consumers protection }\end{array}$ & 5 & 0.01 & 0.01 & 0.01 & 0 & 0.01 & 0.01 & 0.01 & 0.01 & 0 \\
\hline $\begin{array}{l}\text { Reducing the destructive effects on biodiversity and its } \\
\text { various species and natural resources such as forests, } \\
\text { soils, etc. }\end{array}$ & 5 & 0.01 & 0.01 & 0 & 0 & 0.01 & 0.01 & 0 & 0.01 & 0 \\
\hline $\begin{array}{l}\text { Participating in planning and providing training to } \\
\text { train and develop new workforce }\end{array}$ & 4 & 0.02 & 0.01 & 0.01 & 0.01 & 0.01 & 0.01 & 0.01 & 0.01 & 0.01 \\
\hline Importance & & 0.93 & 0.88 & 0.5 & 0.61 & 0.77 & 0.62 & 0.75 & 0.87 & 0.64 \\
\hline
\end{tabular}

Table 6. The final significance of the strategies in the field of requirements for disclosure of CSR performance in descending order.

\begin{tabular}{|c|c|c|c|c|}
\hline & Strategies & $\begin{array}{c}\text { Final } \\
\text { Significance }\end{array}$ & $\begin{array}{c}\text { Relative } \\
\text { Significance }\end{array}$ & $\begin{array}{l}\text { Cumulative } \\
\text { Significance }\end{array}$ \\
\hline 1 & Employee flexibility through learning new business-related skills & 0.93 & 14.16 & 14.16 \\
\hline 2 & $\begin{array}{l}\text { Empowerment through the provision of non-profit support in the } \\
\text { fields of education, health and welfare }\end{array}$ & 0.88 & 13.39 & 27.55 \\
\hline 3 & $\begin{array}{l}\text { Paying attention to all stages of the value chain to increase customer } \\
\text { satisfaction and reduce the cost price }\end{array}$ & 0.87 & 13.24 & 40.79 \\
\hline 4 & $\begin{array}{l}\text { Recycling of dump and waste and reconstruction of destructive } \\
\text { effects caused by the company's business cycle }\end{array}$ & 0.77 & 1.72 & 52.51 \\
\hline 5 & $\begin{array}{l}\text { Maintain quality and make prices competitive by reducing the cost } \\
\text { of products in order to maintain market share }\end{array}$ & 0.75 & 11.42 & 63.93 \\
\hline 6 & $\begin{array}{l}\text { Transparent reporting of financial statements and acceptance of } \\
\text { voluntary auditing of financial statements if no audit services } \\
\text { are required }\end{array}$ & 0.64 & 9.74 & 73.67 \\
\hline 7 & Production of organic and health-oriented products & 0.62 & 9.44 & 83.11 \\
\hline 8 & Timely payment of duties and taxes & 0.61 & 9.28 & 92.39 \\
\hline 9 & $\begin{array}{l}\text { Increasing the quantitative level of employment and supporting the } \\
\text { livelihood of employees }\end{array}$ & 0.5 & 7.61 & 100 \\
\hline
\end{tabular}

\section{Discussion}

In this study, the social responsibility performance of food and pharmaceutical companies listed on the TSE over a period of 6 years during the years 2014-2019 examined. According to the most important unmet requirements, the necessary strategies identified through interviews with experts. Six identified strategies tend to be different in terms of substance.

"Employee flexibility through learning new business-related skills" refers to the training and development of the company's employees.

Furthermore, in the public sphere, "empowerment through the provision of non-profit support in the fields of education, health and welfare" has been emphasized. Therefore, empowering employees and the general public can be considered a common theme for these two strategies. 
The third strategy "paying attention to all stages of the value chain to increase customer satisfaction and reduce the cost price" can also address the company's executive processes. The fourth strategy, "recycling of dump and waste and reconstruction of destructive effects caused by the company's business cycle", is also of the same type.

The fifth strategy, to "maintain quality and make prices competitive by reducing the cost of products in order to maintain market share", can be attributed to the macro and serious customer orientation along with the effects and consequences of the third strategy.

The sixth strategy, "transparent reporting of financial statements and acceptance of voluntary auditing of financial statements if no audit services is required", can also be considered in the field of finance and accounting.

It seems that the set of these strategies follows a specific path of causal relationship that can be addressed in future research. The concept of social responsibility is unfamiliar among pharmaceutical and food companies in Iran. Iranian organizations often show little inclination to apply the principles of social responsibility due to government ownership and lack of need to create a positive mindset among their customers. If pharmaceutical and food companies in Iran can make their shareholders, customers and stakeholders aware of their social performance and strengthen their positive mentality, this positive mentality can reduce costs and, consequently, leads to better financial performance. CSR is inherently a variable that plays a role in the long run. As a result, companies need long-term plans to improve the overall environment of the organization and improve its performance, and vice versa.

Based on the findings, which in general show a significant impact of information disclosure on the performance of companies and also due to social pressures and demand of different groups of society for environmental and social accountability, there is a need for a practical framework for assessing corporate social responsibility using disclosure of environmental information. Furthermore, institutions such as the TSE should require all companies and institutions listed on the stock exchange to disclose information related to social responsibility and environmental performance. Pursuing such a tactic can be expected from the National Productivity Organization and similar institutions.

\section{Conclusions}

The authors of this paper suggest that the discussion on corporate social responsibility and sustainability is a key issue in the current business environment. Sustainability is future-oriented and is concerned with ensuring that the right to choose to use resources in the future is not restricted by current decisions. As the industrial system in society strengthens, the role of companies in relation to their social responsibilities becomes more prominent. This is in line with the view implicit in sustainable development theory in accordance with Ashrafi et al. (2019) about not being limited to financial aspects and having a long-term and comprehensive perspective in determining and pursuing measures related to social responsibility [38]. The authors consider the interconnection of corporate social responsibility and sustainability in view of the digital transformation of both logistics [39], trade networks [40] and sharing economy [41] as a topic for future research. Although CSR has not yet clearly defined the limits for companies in the form of laws, but this issue has been seriously pursued in the industrial sector for many years [42-44].

Considering the weakness of the criteria for measuring sustainable development, the actual assessment of sustainability, as well as the lack of modern government laws that enforce companies to consider such measurements, businesses, as members of society, must consider their social responsibilities in their policies and strategic decisions.

It is also necessary to pay special attention to such cases in order to strengthen the brand and the growth and development of international cooperation, including in the field of export and investment. Moreover, for the legitimacy of the company's activities, in order to promote its desired social image and attract investors and influence shareholders, managers should use the disclosure of environmental and social information as a tool for advertising and increase the company's market value by increasing disclosure. For 
better disclosure of social and environmental responsibility information, it is better to establish mutual cooperation between different organizations, including the Environmental Protection Organization and the compilers of accounting and auditing standards, as well as the Securities Exchange Organization, for better disclosure of information.

One of the limitations of this study is that its method and utilization of experts was long and tedious, which could be done in a better way in the form of think tanks or using new information and communication tools. On the other hand, such a methodology can act as a case study to develop appropriate and more accurate strategies for a particular company to improve the performance of CSR. Despite many limitations, this study pointed to the complete identification of factors affecting the promotion of CSR performance using a mixed approach in methodology (qualitative-quantitative) in effective factors for Iranian companies. The development of a conceptual model can lead to the creation of requirements for the implementation of social responsibilities for the sustainable development of enterprises that help empower human resources in these industries. Iran, as a developing country, is seriously involved in issues and challenges related to sustainable development, and Iranian organizations, with regards to society, environment and economy, play an important role in guiding the development process in the country towards sustainability.

Author Contributions: Conceptualization, M.G.G. and S.E.B.; methodology, S.M.D.; software, M.G.G.; validation, S.E.B. and S.M.D.; formal analysis, T.L.K.; investigation, A.V.K.; resources, O.V.S. and D.I.S.; data curation, A.V.K. and M.G.G.; writing—original draft preparation, S.M.D. and T.L.K. All authors have read and agreed to the published version of the manuscript.

Funding: The research of S.M.D.; S.E.B. and T.L.K. is partially funded by the Ministry of Science and Higher Education of the Russian Federation under the strategic academic leadership program 'Priority 2030' (Agreement 075-15-2021-1333 dated 30 November 2021).

Institutional Review Board Statement: Not applicable.

Informed Consent Statement: Not applicable.

Data Availability Statement: Data sharing is not applicable to this article.

Conflicts of Interest: The authors declare no conflict of interest.

\section{References}

1. Kansal, M.; Joshi, M.; Batra, G.S. Determinants of corporate social responsibility disclosures: Evidence from India. Adv. Account. 2014, 30, 217-229. [CrossRef]

2. Demirag, I. Corporate Social Responsibility, Accountability and Governance: Global Perspectives; Routledge: Oxfordshire, UK, 2018.

3. Monciardini, D.; Mähönen, J.T.; Tsagas, G. Rethinking Non-Financial Reporting: A Blueprint for Structural Regulatory Changes. Account. Econ. Law A Conviv. 2020, 10. [CrossRef]

4. La Torre, M.; Sabelfeld, S.; Blomkvist, M.; Dumay, J. Rebuilding trust: Sustainability and non-financial reporting and the European Union regulation. Meditari Account. Res. 2020, 28, 701-725. [CrossRef]

5. Jitmaneeroj, B. Reform priorities for corporate sustainability. Manag. Decis. 2016, 54, 1497-1521. [CrossRef]

6. Farcane, N.; Bureana, E. History of "Corporate social responsibility" concept. Ann. Univ. Apulensis Ser. Oecon. $2015,17,31$. [CrossRef]

7. Lindgreen, A.; Swaen, V. Corporate Social Responsibility. Int. J. Manag. Rev. 2010, 12, 1-7. [CrossRef]

8. Jáčová, H.; Horák, J. The analysis of selected resource management tools used in the Czech Republic. Int. J. Sustain. Dev. Plan. 2015, 10, 666-684. [CrossRef]

9. Taghian, M.; D'Souza, C.; Polonsky, M. A stakeholder approach to corporate social responsibility, reputation and business performance. Soc. Responsib. J. 2015, 11, 340-363. [CrossRef]

10. Abad-Segura, E.; Cortés-García, F.J.; Belmonte-Ureña, L.J. The sustainable approach to corporate social responsibility: A global analysis and future trends. Sustainability 2019, 11, 5382. [CrossRef]

11. Yoon, B.; Chung, Y. The effects of corporate social responsibility on firm performance: A stakeholder approach. J. Hosp. Tour. Manag. 2018, 37, 89-96. [CrossRef]

12. Carroll, A.B.; Brown, J.A. Corporate social responsibility: A review of current concepts, research, and issues. Corp. Soc. Responsib. 2018, 2, 39-69.

13. Maqbool, S.; Zameer, M.N. Corporate social responsibility and financial performance: An empirical analysis of Indian banks. Future Bus. J. 2018, 4, 84-93. [CrossRef] 
14. Hunger, J.D. Essentials of Strategic Management. 2020. Available online: http://elibrary.gci.edu.np/bitstream/123456789/718/ 1/BM\%20-542\%20Essentials\%20of\%20Strategic\%20Management $\% 2$ C $\% 205$ th\%20Edition\%20by \%20J.\%20David\%20Hunger\% 2C\%20Thomas\%20L.\%20Wheelen.pdf (accessed on 15 July 2021).

15. Daniali, S.; Mohammadbeigi, K. Knowledge management in the field of risk management in a corporate environment, Iran's oil industry. Upravlenie 2020, 8, 63-73. [CrossRef]

16. Revathy, B. Corporate social responsibility-an implementation guide for business. Far East J. Psychol. Bus. 2012, 6, 15-31.

17. Żelazna, A.; Bojar, M.; Bojar, E. Corporate Social Responsibility towards the Environment in Lublin Region, Poland: A comparative study of 2009 and 2019. Sustainability 2020, 12, 4463. [CrossRef]

18. Camilleri, M.A. Corporate sustainability and responsibility: Creating value for business, society and the environment. Asian J. Sustain. Soc. Responsib. 2017, 2, 59-74. [CrossRef]

19. Ferson, W.E. Investment performance evaluation. Annu. Rev. Financ. Econ. 2010, 2, 207-234. [CrossRef]

20. Effati, M.; Alaauddin, R.; Maryam, P. Performance Management (with a View to Evaluating the Performance of Executive Bodies) Theoretical Foundations, Step-by-Step Method of Implementation, Legal Foundations and Documentation; Farmanesh: Tehran, Iran, 2007.

21. Graafland, J.; Eijffinger, S. Corporate social responsibility of Dutch companies: Benchmarking, transparency and robustness. De Econ. 2004, 152, 403-426. [CrossRef]

22. Corporate Social Responsibility. CSR and Socially Responsible Investing Strategies in Transitioning and Emerging Economies. 2020, Volume 65. Available online: https://www.google.com/books?hl=en\&lr=\&id=tdHMDwAAQBAJ\&oi=fnd\&pg=PA65\&dq= .+Corporate+Social+Responsibility\&ots=N_5R976mDK\&sig=QkuRj6RfqxEO21TpcdU0V9PCgaU (accessed on 15 July 2021).

23. Low, M.P. Corporate social responsibility and the evolution of internal corporate social responsibility in 21st century. Asian J. Soc. Sci. Manag. Stud. 2016, 3, 56-74. [CrossRef]

24. Górny, A. Influence of corporate social responsibility (CSR) on safety culture. Management 2014, 18, 43-57. [CrossRef]

25. Deus, R.M.; Seles, B.M.R.P.; Vieira, K.R.O.; Battistelle, R.A.G. Organisational challenges to corporate social responsibility. In ISO 26000-A Standardized View on Corporate Social Responsibility; Springer: Berlin/Heidelberg, Germany, 2019; pp. $207-219$.

26. Faller, C.M.; zu Knyphausen-Aufseß, D. Does equity ownership matter for corporate social responsibility? A literature review of theories and recent empirical findings. J. Bus. Ethics 2018, 150, 15-40. [CrossRef]

27. Greenfield, K. The impact of going private on corporate stakeholders. Brook. J. Corp. Fin. Com. Law 2008, 3, 75.

28. Miras Rodríguez, M.d.M.; Escobar Pérez, B.; Carrasco Gallego, A. Are Spanish listed firms betting on CSR during the crisis? Evidence from the agency problem. Bus. Manag. Res. 2014, 3, 85-95.

29. Garel, A.; Petit-Romec, A. Investor Horizons and Employee Satisfaction: A test of the long-term perspective vision of CSR. Econ. Bull. 2020, 40, 765-781.

30. Bassen, A.; Meyer, K.; Schlange, J. The Influence of Corporate Responsibility on the Cost of Capital. 2006. Available online: https:/ / ssrn.com/abstract=984406 (accessed on 15 July 2021).

31. Kongerloui, J.; Anwar, B. Investigating the Relationship between Social Responsibility and Organizational Commitment with Conservatism in Financial Reporting of Companies Listed on Tehran Stock Exchange. Stock. Exch. Q. 2010, 3, 77-96.

32. Cheah, E.T.; Chan, W.L.; Chieng, C.L.L. The corporate social responsibility of pharmaceutical product recalls: An empirical examination of US and UK markets. J. Bus. Ethics 2007, 76, 427-449. [CrossRef]

33. Chan, P.; Lee, M.-H. Developing sustainable city indicators for Cambodia through Delphi processes of panel surveys. Sustainability 2019, 11, 3166. [CrossRef]

34. Perveen, S.; Kamruzzaman, M.; Yigitcanlar, T. Developing policy scenarios for sustainable urban growth management: A Delphi approach. Sustainability 2017, 9, 1787. [CrossRef]

35. Agrawal, T.K.; Pal, R. Traceability in textile and clothing supply chains: Classifying implementation factors and information sets via Delphi study. Sustainability 2019, 11, 1698. [CrossRef]

36. Gupta, U.G.; Clarke, R.E. Theory and applications of the Delphi technique: A bibliography (1975-1994). Technol. Forecast. Soc. Chang. 1996, 53, 185-211. [CrossRef]

37. Wasserman, G.S. On how to prioritize design requirements during the QFD planning process. IIE Trans. 1993, $25,59-65$. [CrossRef]

38. Ashrafi, J.; Roodposhty, F.R.; Banimahd, B. Corporates Social Responsibility Theories. Manag. Account. Audit. Knowl. 2019, 8, 1-14.

39. Barykin, S.Y.; Kapustina, I.V.; Sergeev, S.M.; Kalinina, O.V.; Vilken, V.V.; de la Poza, E.; Putikhin, Y.Y.; Volkova, L.V. Developing the physical distribution digital twin model within the trade network. Acad. Strateg. Manag. J. 2021, 20, 1-18.

40. Barykin, S.Y.; Smirnova, E.; Sharapaev, P.; Mottaeva, A. Development of the kazakhstan digital retail chains within the eaeu e-commerce market. Acad. Strateg. Manag. J. 2021, 20,1-18.

41. Barykin, S.Y.; Kapustina, I.V.; Kalinina, O.V.; Dubolazov, V.A.; Esquivel, C.A.N.; Alyarovna, N.E.; Sharapaev, P. The sharing economy and digital logistics in retail chains: Opportunities and threats. Acad. Strateg. Manag. J. 2021, 20, 1-14.

42. An, J.; Mikhaylov, A.; Jung, S.-U. A Linear Programming approach for robust network revenue management in the airline industry. J. Air Transp. Manag. 2021, 91, 101979. [CrossRef]

43. Mikhaylov, A.Y. Development of Friedrich von Hayek's theory of private money and economic implications for digital currencies. Terra Econ. 2021, 19, 53-62. [CrossRef]

44. An, J.; Mikhaylov, A.; Richter, U.H. Trade war effects: Evidence from sectors of energy and resources in Africa. Heliyon 2020, 6, e05693. [CrossRef] 